\title{
The Transformation of the Crimean Tatars' Institutions and Discourses After 2014
}

\author{
Elmira Muratova \\ Crimean Federal University
}

\begin{abstract}
The article deals with the transformation of the Crimean Tatars' institutions and discourses after the 2014 conflict around Crimea. It shows the change in the balance of power of traditional institutions such as Mejlis and Muftiyat, which for many years represented secular and religious components of Crimean Tatars' ethnic identity. It tells how the Mejlis was dismissed from the political stage in Crimea, while the Muftiyat has enjoyed a great support by new authorities. This transformation and threats to societal security inevitably led to reassessment of previous views and goals of the main actors in the Crimean Tatar community and the formation of new institutions with hybrid composition and discourse. The article focuses on organization such as 'Crimean solidarity,' which was formed in 2016 as a reaction to authorities' pressure over the Crimean Tatars. Using discourse analysis of statements of activists of this organization and content analysis of social media, the author presents the main topics of its discourse and types of activity. She shows how the traditional Islamic discourse of activists of this organization has been transformed by the incorporation of the main concepts of secular discourse developed by the Mejlis. The author argues that the appearance of 'Crimean solidarity' indicates the blurring of lines between secular and religious, and ethnic and Islamic in the Crimean Tatar society. It shows how people with different backgrounds and agendas manage to leave their differences aside to support each other in the face of a common threat.
\end{abstract}

\section{Keywords}

Crimean Tatars; Transformation; Hybridity; Institutions; Discourses; Mejlis; Muftiyat; Crimean Solidarity

\section{Introduction}

The Crimean Tatars' fate after the 2014 Crimea's annexation by Russia is gradually becoming an object of studies. Some of them pay tribute to the complexity of the relationship between the Crimean Tatars and Russian state due to certain developments in the past. These were the first Crimea's annexation

\footnotetext{
* Elmira Muratova, Department of Political Science and International Relations, Faculty of Philosophy, Crimean Federal University, Prospekt Vernadskogo 4, Simferopol, Crimea. The article has been written as the part of the research project within the Freedom Chair Fellowship of the Prague Civil Society Center (2018); murelmira@googlemail.com.
} 
by the Russian Empire in 1783 and the deportation of the Crimean Tatars by the Soviet regime in May 1944, which are crucial for shaping the Crimean Tatars' perception of Russian policy in contemporary Crimea. Some authors discuss the importance of these events in the development of victimization narratives and political mobilization of the Crimean Tatars (Nikolko 2018, Ozcelik 2015). They point to the change in the politics of memory in annexed Crimea, where "depolitization together with generalization of the memorial dates and events is followed by unification of memorial practices" (Nikolko 2018, 88). Nikolko stressed that the repressive trends developing in Crimea provided a very little hope for fair research and public discussion of the traumatic past in Crimea. According to her, the "new authorities returned to the 1994 interpretation of the event, when May 18 was set as day of commemoration of the deportation's victims without any particular ethnic connotation. The Soviet discourse of ignorance of the trauma of a particular indigenous ethnic group was revitalized once again" (Nikolko 2018, 89).

Buhari-Gulmez' study focuses on the Crimean Tatar self-determination movement showing the discursive shift from "deportation crisis" to "annexation crisis" in the Crimean Tatar community, including the diaspora. She argued that since 2014 Crimean Tatars tend to represent the Russian annexation of Crimea as "the crisis" referring to the deinstitutionalization of Crimean Tatar political agency in Crimea and the increasing "invisibility" of Crimean Tatar self-determination claims given the ongoing "hegemonic struggles" over who represents Crimean Tatars (Buhari-Gulmez 2018, 219220).

Žídková and Melichar, using the framework of societal security (sustainable development of traditional patterns of language, culture, and national identity), argued that, based on the proclamations by the leaders and interviews with ordinary Crimean Tatars, "there is no doubt that the majority of Tatars feels threatened" (Žídková and Melichar 2015, 102). They presented examples of Russia's pressure over the Crimean Tatars and argued that several necessary conditions to precipitate fear within societal groups can be found in the Crimea: negative group stereotypes, threatened ethnic symbols (flags, statues), and a threatened demographic situation (Žídková and Melichar 2015, 104). They also raised the questions of how can the Crimean Tatar society react to these threats to their identity and why does the Crimean Tatar resistance remain nonviolent? According to Žídková and Melichar, there are several reasons for nonviolent resistance. First, the Crimean Tatars constitute roughly twelve percent of the Crimean population, and any attempt to start an armed resistance would result in ultimate failure against the superior 
military power of the Russian majority. Second, no paramilitary organization exists that would safeguard the interests of the Crimean Tatars. Third, the Crimean authorities, as well as the Russian army, would undoubtedly use this opportunity to introduce even harsher repressions against the Tatar minority. Fourth, most of the societal threats in Crimea are connected with legal or bureaucratic discrimination, which as a rule provokes nonmilitary responses (Žídková and Melichar 2015, 105).

Other scholars have also shown an interest in the ways of the Crimean Tatars' actual and future resistance to Russia. Ozcelik has analyzed them within the framework of conflict analysis and peace studies fields, paying particular attention to the nonviolent nature of the Crimean Tatar National Movement as a prerequisite for peaceful resistance in nowadays Crimea (Ozcelik 2015, 12). Among other factors, Ozcelik pointed to the small size of the Crimean Tatar nation, the embodiment of nonviolence in the Crimean Tatar popular culture, and their close historical ties to the Soviet dissident movements (Ozcelik 2015, 14).

Besides victimization narratives and ways of resistance, some attention has also been paid to identity and institutional changes within the Crimean Tatar people, particularly to the divide and rule policy (Wilson 2017) and relationships of the Crimean Tatar's Mejlis and Muftiyat with new Crimean authorities and each other (Muratova 2016). These studies have shown the rise of tensions between these two institutions as cooperation between Muftiyat and authorities was increasing while the Mejlis was pushed out of the political sphere of Crimea. Wilson has paid attention to various identity politics in Crimea and Ukraine saying that the biggest impact of the Crimean Tatar issue since 2014 has been on helping to reshape Ukrainian national identity and nationalism (Wilson 2017, 45).

While scholarship on post-2014 developments in Crimea provides a general picture of the situation, there are important issues that have not received their coverage yet. Among them is the transformation of the Crimean Tatar institutions and discourses and their hybridization, which is understood as the formation of new institutions with mixed, heterogeneous composition and discourse. This process, based on discourse analysis of statements of members of "Crimean solidarity" (Krymskaya solidarnost') and content analysis of media, is the focus of this article. The main research questions can be formulated in the following way: what are the structural and ideological components of 'Crimean solidarity' as a hybrid organization and how effective is it in satisfying the community's needs in a time of the post-2014 crisis? 
The Transformation of the Crimean Tatars' Institutions and Discourses After 2014

The article is organized in the following manner. First, I provide an overview of the theoretical concepts of hybridity and hybrid organization in the context of third-sector research. Second, I give a general picture of institutional development within the Crimean Tatar community after repatriation, by showing the Mejlis and Muftiyat's positions and discourses. Third, I discuss changes in relations between these two institutions and their influence on the Crimean Tatars after the 2014 Crimea's annexation. Finally, in the fourth part of the article, I show the transformation of the Crimean Tatars' institutions and discourses on the example of 'Crimean solidarity' organization. In conclusion, I go back to the concept of hybridity to summarize my thoughts on the current and future developments around the 'Crimean solidarity'.

\section{Hybridity and Hybrid Organizations in the Context of Third-Sector Research}

The concept of hybridity is well known in a variety of disciplines, from linguistics, cultural studies, and technology to biology. The term 'hybridity' has been used on various occasions and, as Bassi states, became one of the crossborder concepts able to 'pollinate' to 'fertilize' different fields of thought and to open new frontiers in the development of knowledge (Bassi 2014, 397). In social evolution theory, the term 'hybridity' traditionally carried the connotation of being 'impure,' 'rationally contaminated,' and genetically 'deviant' but in the late twentieth century has been reappropriated to signal cultural synthesis (Ifekwunigwe 1999, 188). In the recent decades, hybridity is used within cultural and postcolonial studies, and the term is often related to studies of diasporas, immigration, and biculturalism, and questions about new identities and ethnicities (Pelliccia 2017, 55).

In this paper, the concept of hybridity applies to the organizational level. Hybridity, together with hybrid organizations, appears as a multidimensional concept that is discussed within different contexts. In the nonprofit sector (i.e. third sector) studies, hybridity typically refers to the complex organizational forms that arise as voluntary, charitable, and community organizations confront differentiated task, legitimacy, or resource environments (Skelcher and Smith 2015, 433). Many scholars agree that hybridity in the third sector is not a new phenomenon. For many years, some organizations have moved into hybridity in a rather gentle manner, causing minor disturbances but not necessarily calling into question their basic third-sector identity (Billis 2010, 60). Some even argue that the third-sector organizations are inherently hybrids because they tend to contain different missions and values connected to the community, markets, and the state (Smith 2010, 220). 
Although in each disciplinary context hybridity means something different in detail, a basic definition is common to all of them: "a mixture of essentially contradictory and conflicting elements" (Brandsen and Karré 2011, 828). Scholars tend to agree that hybrid organizations contain mixed sectoral, legal, structural, and/or mission-related elements (Smith 2010, 220). They are therefore seen as "heterogeneous arrangements, characterized by mixtures of pure and incongruous origins, (ideal)types, 'cultures,' 'coordination mechanisms,' 'rationalities,' or 'action logics" (Brandsen et al. 2005, 750).

Scholars believe that it is very likely that hybrid organizations spring up in response to periods of crises (economic, political, social, etc.) (Bassi 2014, 399) or 'environmental uncertainty' (Smith 2010, 220) when traditional solutions to broad social problems do not seem to address the challenges introduced by the new institutional environment. Often hybrids are better able to adapt to turbulent environments than the two original (pure) organizational forms from which they originate (Bassi 2014, 400). The essential combination of different organizational principles proves to be advantageous and allows them to react more flexible and without being tied to one specific logic of action.

Theorizing hybridity, scholars attempted to propose typologies of hybrids in the third sector. Thus, Billis offers the concepts of (a) 'shallow' and 'entrenched' hybrids and (b) 'organic' and 'enacted' hybrids. The 'shallow hybrid' is an organization in which the process of hybridization is very low, light, or superficial. Alternatively, an 'entrenched hybrid' is an organization in which the process of hybridization is very profound and deep and involves both the governance and operational levels of the organization (Billis 2010, 59). The 'organic hybrid' is an organization that is born as a pure, single-sector type (public, private, and third sector) moving slowly, during its life cycle, toward a more hybrid organizational form. The 'enacted hybrid', in contrast, is an organization that from the beginning is established as a hybrid (Billis 2010, 61). Billis hypothesized that nowadays we are facing a double movement from 'shallow hybrid' to 'entrenched hybrid' and from 'organic hybrid' to 'enacted hybrid' (Billis 2010, 65).

Skelcher and Smith argued that hybridization arises from a plurality of rationalities - which they termed 'institutional logics' (Skelcher and Smith $2015,434)$. They viewed hybridization as a process in which plural logics and thus actor identities are in play within an organization, leading to several possible organizational outcomes. Based on this, they proposed five types of hybrids: segmented, segregated, assimilated, blended, and blocked (Skelcher and Smith 2015, 440). In the assimilated hybrid, which is used in this article to describe the 'Crimean solidarity' organization, the core or original logic 
remains but the organization adopts some of the practices and symbols of a new logic. The organization reflects the expectations of the new logic in terms of its structure, symbols, and language but in its day-to-day practice continues to operate in line with its institutional origins (Skelcher and Smith 2015, 441-442).

The concept of hybridity in this paper is used to describe the transformation of the traditional Crimean Tatar institutions and discourses in the situation of crisis and uncertainty caused by the 2014 annexation of Crimea. Hybridity here is understood as the blurring of boundaries between (a) secular and religious and (b) ethnic and Islamic in the Crimean Tatar community. As the last part of the paper shows, the 'Crimean solidarity' as a hybrid organization appeared to present more effective in serving the community's needs model of organization compared to other institutions with more 'pure' nature.

\section{The Main Crimean Tatar Institutions and Discourses After Repatriation}

After the return of the Crimean Tatar people from the places of deportation to Crimea in the early 1990 s, they managed to create a fairly effective system of ethnic institutions to deal with political, legal, socioeconomic, and religious issues of repatriates (Shevel 2000, 9-10). Among these institutions, the most influential were the Mejlis of the Crimean Tatar people and the Spiritual Administration of Muslims of Crimea (SAMC; Dukhovnoe upravlenie musul'man Kryma), which represented two components of Crimean Tatars' ethnic identity - secular and religious.

The Mejlis has functioned as a representative body of the Crimean Tatars both in relations to the Ukrainian state, where the Crimean Tatars found themselves after repatriation, and to the foreign states and organizations. It was elected by the national congress of the Crimean Tatars (Qurultai) for a term of five years, which allowed its leaders to speak on behalf of the entire Crimean Tatar people (Osipov 2014, 5). For a long time, the Mejlis defined the main outlines of the Crimean Tatar agenda - people's attitude toward political events and actors and socioeconomic and cultural processes in Crimea and Ukraine. Although there was opposition to the Mejlis within the Crimean Tatar community, the level of its legitimacy has traditionally been high. Moreover, for many Crimean Tatars in the situation of absence of their national statehood, the Mejlis represented an ethnic 'government' to which they addressed their expectations and claims (Kouts and Muratova 2014, 38-41).

The Mejlis was a secular institution, the main ideology of which was the Crimean Tatar nationalism. Its leaders expressed their wish for selfdetermination in the 1991 Declaration of National Sovereignty of the 
Crimean Tatar people, which declared that "Crimea is a national territory of the Crimean Tatar people, on which they alone possess the right to selfdetermination" and "the political, economic, spiritual, and cultural rebirth of the Crimean Tatar people is possible only in their sovereign national state" (Allworth, 1998, 353). Later, this wish obtained more concrete form - the Crimean Tatar national territorial autonomy within the Ukrainian state (Shevel 2000, 11). An important place in the politics of Mejlis was occupied by the discourse of deportation (surgun) - the collective trauma of the Crimean Tatars, to commemoration of which was devoted many activities and initiatives. For a long time (since the establishment of the Mejlis in 1991 until 2013), the chairman of the Mejlis was a former Soviet dissident Mustafa Dzhemilev, whose personality largely predetermined an ideological orientation of the Mejlis, particularly its rejection of the Soviet regime, nonviolent methods of struggle, and support for democratic forces in Ukraine (Ozcelik 2015, 13-14). Despite the dominance of secular views, the leadership of the Mejlis often appealed to Islam as an important component of the historical and cultural tradition of the Crimean Tatars. At the same time, all ideologies that proclaimed the primacy of religion over ethnicity were rejected by it as alien and harmful to the Crimean Tatars, such as those that can lead to the assimilation of the people, its dissolution among the world Muslim Ummah (Vystuplenie ...2008).

The SAMC (or simply Muftiyat) was a centralized institution established in 1992 to regulate processes in the religious sphere of the Crimean Tatars' life. The Muftiyat was formed with the direct participation of the Mejlis, which led to very close relations of two institutions in the coming years. These relationships were so close that some opponents of the SAMC often accused it of being dependent on Mejlis, calling it, 'the department of the Mejlis' or the 'pocket Muftiyat' (Muratova 2016, 164). This dependency was particularly evident from the active participation of the SAMC in the political initiatives of the Mejlis, which resulted in a reduction of its legitimacy among those Crimean Tatars who were in opposition to the Mejlis and also among those Muslims who did not support nationalism at all. To create a complete picture of the relationships between two institutions, we can add that the third mufti of the SAMC, Emirali Ablaev, who has held this post since 1999, was also a member of the Mejlis.

The main ideology of the SAMC, as the charter of this organization says, was Islam, according to which the Muftiyat has to carry out its activities. An important concept of the SAMC discourse was the concept of 'traditional' or 'Crimean' Islam, which was understood as Islam rooted in the Crimean Tatar 
tradition (Muratova 2008, 67). This concept did not have much circulation in Crimea in the early 1990s, when Muftiyat and Mejlis actively asked Muslim countries and organizations for help in the revival of Islam, but began to acquire a loud sound by the early 2000s. Then, among the Crimean Tatars appeared followers of various Islamic movements, some of whom critically evaluated religious traditions of the Crimean Tatars and criticized them for departing from Islam. In this situation, the SAMC with the support of the Mejlis launched activities to combat 'non-traditional' Islamic groups, which at that time were represented by the followers of Salafism, Hizb ut-Tahrir (HT), Muslim Brotherhood, etc.

In general, the secular discourse of the Mejlis was dominant among the Crimean Tatars throughout the Ukrainian period of post-Soviet Crimea. According to it, the Crimean Tatars are the indigenous people of Crimea, formed on its territory during a long process of ethnogenesis, which involved representatives of all peoples and groups that inhabited Crimea since ancient times (Williams 2015, 144; Yapici 2018). The fact that some European people (like the Greeks and Romans) took part in the ethnogenesis of the Crimean Tatars, according to the leaders of the Mejlis, explains that Crimean Tatars have a strong European identity and support for pro-European political forces in Ukraine (Wilson 2017, 28). According to Wilson, the idea of European identity also has its roots in the long history of the Crimean Tatar National Movement's appeals to international organizations. The Mejlis' leaders often stressed that Crimean Tatars are Muslims whose religion has never been the fundamentalist or radical but, on the contrary, historically has been tolerant toward non-Muslims (Vozgrin 2013, 336, 361). The Crimean Tatars are a victim nation, which has repeatedly suffered from the machinations of the Russian/Soviet state. The collective memory of the Crimean Tatars contains two main events that played an important role in the history of the people. These were the annexation of Crimea by the Russian Empire in 1783 and the deportation of Crimean Tatars from Crimea in 1944. Particularly, the deportation became a 'chosen trauma,' an important source of the ethnic group identity creation and maintenance (Ozcelik 2015, 15). Throughout the whole post-Soviet period of Crimea, victimization narratives, strongly encouraged by the Mejlis, contributed to the political mobilization of the Crimean Tatars. The fixation on the oppressor (Russia/Soviet regime) has become one of the

1 During these years, Qurultay in Crimea adopted several resolutions condemning nontraditional Islamic groups and calling for the preservation of spiritual unity. See, for example, "Postanovlenie Kurultaya krymskotatarskogo naroda ' $\mathrm{O}$ zadachakh organov natsional'nogo samoupravleniya po ukrepleniyu dukhovnogo edinstva krymskotatarskogo naroda' [Resolution of the Qurultay of the Crimean Tatar people 'On the tasks of national self-government bodies to strengthen the spiritual unity of the Crimean Tatar people']," December 2009. 
primary motivation factors for their active political involvement (Nikolko 2018, 82).

The dissemination of the main messages of the Mejlis discourse was ensured through a set of events dedicated to the memorable dates of the Crimean Tatar history, the activities of the Crimean Tatar media, and the creation of a wide arsenal of aesthetic and cognitive means (monuments, works of art, autobiographical, and other works, as well as paintings and images, historical archives, books, and documentary and drama films) that contributed to the formation of the cultural memory of people.

The discourse of the SAMC contained the same messages of the secular discourse and simply added religious nuances in explanation of certain themes, for example the first annexation and deportation. If secular discourse among the reasons pointed exclusively to political factors - the decline of the Ottoman Empire, Russia's expansionist policy, dislike of the Crimean Tatars, etc. - the religious discourse reminded the Crimean Tatars of the root cause of all their troubles - their indifference toward their religion. It was because of the departure of the Crimean Tatars from Islam that God turned them into a victim of the neighboring (infidel) state (Kouts and Muratova 2014, 30-31). This particular interpretation of the reasons of the annexation and deportation was given by imams of Crimean mosques on the eve of deportation each year.

\section{The Fate of the Mejlis and Muftiyat After 2014}

In spring 2014, Crimea has been de facto transferred from Ukrainian state to a Russian country "with an authoritarian overcentralized government, fake multi-party system, the massive state-sponsored propaganda campaigns, effective repressive machinery and no such luxuries as freedom of speech, fair and transparent elections or independent judiciary" (Osipov 2014, 9-10). From the beginning, experts foresaw the risks of pressure, intimidation, and persecutions an independent Crimean Tatar movement can face in Russia (Osipov 2014, 10).

The annexation of Crimea radically changed the balance of power within the Crimean Tatar people. A crucial step for this was Russia's ban of the Mejlis as an 'extremist' organization. This decision was not taken immediately after the annexation. Initially, the new authorities of Crimea tried to establish cooperation with the Mejlis: in March-April 2014, there were negotiations on the distribution of seats in the high-ranking positions of the Crimean Republic with regard of the Crimean Tatar representation in them. However, these negotiations reached an impasse by the summer of 2014 when it became clear that the regime does not allow engagement but requires complete submission 
(Aydin 2014, 90), and soon after that, the relationships between authorities and the Mejlis turned into a conflict and decisions on deportation and ban on entry to Crimea to Mustafa Dzhemilev, Refat Chubarov (chairman of the Mejlis since 2013), and a number of other Mejlis activists followed. Only after the plan to subordinate the Mejlis by replacing its leadership by loyal Crimean Tatars failed (Wilson 2017, 39), in 2016, the Supreme Court of Crimea recognized the Mejlis as an extremist organization and banned its activity in the Russian Federation (Yapici 2018, 318; Nikolko 2018, 88). The inability to control the Mejlis, the pro-Western orientation of its leaders, combined with their ability of mass political mobilization of the Crimean Tatars predetermined the desire of the Russian authorities to get rid of the organization that could interfere with their policy toward the Crimean Tatars. Nowadays, the Mejlis continues to operate in Kyiv, where its leaders and some members of the organization live, but it can no longer have a real impact on the situation in Crimea. Those members of the Mejlis, who remained in Crimea, are trying to maintain connections between regional and local branches but can no longer hold any public actions.

To fill out the vacuum created by the expulsion of the Mejlis, the Russian authorities attempted to create several loyal Crimean Tatar organizations that could contribute to the formation of Russian civil identity among the Crimean Tatars (Yapici 2018, 319). These initiatives involved both former Mejlis functionaries and those who were in opposition to it. There were organizations 'Crimea' (Kyrym) headed by the former deputy chairman of the Mejlis and now the deputy chairman of the Crimean parliament Remzi Ilyasov and 'Our Crimea' (Bizim Kyrym) headed by the former head of the Genichesk district administration in southern Ukraine Seytumer Nimetullayev. However, all their attempts to get mass support of the Crimean Tatars and to convince them for more active involvement in civic life of the Russian Crimea (for example, to participate in parliamentary and presidential elections) ended in nothing and both organizations exist in many respects formally (Wilson 2017, 39).

The fate of the SAMC, in contrast to the Mejlis, turned out differently. Initially (during the summer-autumn 2014), this institution had experienced serious pressure from the new authorities, which took place in different forms (Muratova 2016, 166). There were searches in mosques, withdrawal of forbidden in Russia religious literature, and checks of madrasas by various agencies (Dollenberg 2014). There was also the creation of another centralized Muslim structure - the Taurida Muftiyat (Tavricheskiy Muftiyat) - in 2014, which from the very beginning declared its pro-Russian position and a desire 
to become the main Muslim organization in the Russian Crimea (Novyi Tavricheskiy...2014). There were also quite frequent visits to Crimea by delegations of Muslim organizations of Russia, who told the Crimean mufti about the prospects for Muslims in Russia and the benefits of cooperation with the Russian authorities (Dzhabrail 2014). All these eventually led the SAMC to the idea of the need for cooperation with the new government as the only way to preserve its status as a centralized Muslim body and control over the mosques and madrasas in the peninsula. As a result, against the background of the authorities' pressure on the Mejlis and its squeezing out of the public space of Crimea, the SAMC did not lose its position and even strengthened it. All mosques and madrasas operating in Crimea were transferred under the direct jurisdiction of the Muftiyat (Vse mecheti Kryma...2018). The mufti and his deputies became mandatory guests at all public events held by the authorities in Crimea (Muratova 2016, 169). Furthermore, the Russian authorities have launched a process of building a huge Cathedral mosque in Simferopol, which is presented as a clear illustration of the positive changes in the life of the Crimean Muslims. Financial support of the SAMC through various near-state institutions was established, and this allowed increasing its staff, publishing religious literature, and conducting scientific and educational activities.

Such a 'rise' of the Muftiyat naturally affected its relationships with the Mejlis. With the stronger inclusion of the SAMC into the orbit of Russian influence, these relations started to deteriorate. The Muftiyat was used by the Russian authorities to criticize the Mejlis and undermine its influence among the Crimean Tatars. Pushed by the authorities, the SAMC initiated several public events, where statements with severest critics of the Mejlis leaders' initiatives were made. ${ }^{2}$ All these have contributed to that relationship between former allies developed into an open conflict, accompanied by mutual accusations and personal insults. The Mejlis accused the leaders of the SAMC for collaboration, corruption, and betrayal of the interests of the people (Dzhemilev...2016). In its turn, the Muftiyat retorted that unlike the leaders of the Mejlis, it remains with its people in their homeland and continues to work for their benefit (Kto podstavlyaet...2016). The tough rhetoric against the leaders of the Mejlis, which was previously unusual for the SAMC, affected its legitimacy, pushing away a significant number of the Crimean Tatars who did not have pro-

2 Particularly, statements were criticizing the food and energy blockades of Crimea and the formation of the Crimean Tatar battalion within the Ukrainian armed forces fighting in the Donbas area (Wilson 2017: 30). 
Russian sentiments. ${ }^{3}$ The formation with the support of the Mejlis of a parallel SAMC in Kyiv in November 2016 has contributed to the weakening of the position of the Crimean Muftiyat abroad (V Kieve sozdano...2016). ${ }^{4}$ Thus, today two institutions claim to be spiritual centers of Crimean Muslims: one recognized by some post-Soviet Muslim communities in Crimea and another recognized by the wider Muslim and international community in Kyiv.

As a result of institutional changes and especially Mejlis' dismissal from the political stage, the Crimean Tatars narratives in media lost their civic and political 'colors.' Now the community is represented in the Crimean media mainly by religious leaders and is thus positioned as a Muslim community, not much as an indigenous group or a politically motivated group. The dramatic transformation has also affected the narratives of memories and remembering practices of deportation. The new authorities returned to the 1994 interpretation of the event, when May 18 was set as a day of commemoration of the deportation's victims without any particular ethnic connotation. The Soviet discourse of ignorance of the trauma of a particular indigenous ethnic group was revitalized once again (Nikolko 2018, 89).

\section{The Phenomenon of 'Crimean solidarity'}

The real and imagined threats to societal security, understood as "ability of a society to persist under changing conditions and possible and actual threats" (Waever 1993, 23), manifested in deportations of the Mejlis leaders, deliberate interments, criminal prosecution, and murders of the participants of the pro-Ukraine demonstrations (Žídková and Melichar 2015, 101-102), forced the Crimean Tatar community to reconsider its previous views and goals. The change in the balance of power within the Crimean Tatar people after 2014 was accompanied not only by a change in influence and positions of the main players but also by the transformation of previous coalitions and discourses. The former dividing line between supporters of the Mejlis and the SAMC, as promoters of the Crimean Tatar identity, on the one hand, and various Islamic groups, who advocated for universal Islamic identity, on the other hand, has disappeared. New coalitions of organizations and groups with new discourses have emerged. In this regard, an interesting phenomenon is 'Crimean solidarity,' an organization whose appearance before Crimea's annexation was unthinkable.

3 It was evident from the focus group and individual interviews of the study "The values and needs of the Crimean Tatars" conducted in 2017-2019 in Crimea. The study was conducted by the author of the paper together with Alime Apselyamova and Lenora Dyulber.

4 The mufti of the SAMC in Kyiv became Ayder Rustamov who from 2015 headed the Committee of Spiritual Values of Muslims in the community of Crimean Tatars in Kyiv. 
As an independent organization, 'Crimean solidarity' appeared in April 2016 on the basis of the Crimean contact group (Krymskaya kontaktnaya gruppa) formed by the member of the Crimean Tatar National Movement ${ }^{5}$ (Krymskotatarskoe natsional'noe dvidzenie) Abdureshit Dzhepparov at the end of 2015. This group appeared as a reaction to the facts of the kidnapping of the Crimean Tatars, which began to take place in the annexed Crimea (Shakirov 2014). The task of the contact group was to coordinate the efforts of the families of the victims, law enforcement agencies, as well as the Crimean authorities in the search for missing people. Initially, the group was able to conduct a dialog with the authorities (Kontaktnaya gruppa...2014), but in 2016, when the searches and arrests of Crimean Tatars took massive forms, the authorities stopped all contacts with the group. As a result, it went through reorganization and reorientation and made an emphasis on human rights and charity initiatives.

When the Crimean contact group has been transformed into the 'Crimean solidarity,' it united families of more than 20 arrested and detained Crimean Tatars, their lawyers, members of the Crimean Tatar National Movement, the Mejlis, journalists, public activists, and other sympathizers. All these people, who previously belonged to different organizations and had different (sometimes opposed) positions and views, became united by the rejection of the Russian policy of pressure on the Crimean Tatars and, in general, the Russian status of Crimea.

The 'Crimean solidarity' is structured horizontally and consists of several groups of people responsible for a particular type of activity. These groups operate voluntarily and are coordinated by a person who is officially called the coordinator. In 2016-2018, Server Mustafaev held this position until he was arrested. Currently, the duties of the coordinator are performed by Dilyaver Memetov. ${ }^{6}$ There is no fixed membership in the organization. Anyone can join or leave it at any time. The core of those responsible for a particular type of activity is not permanent due to the constant detentions and arrests of the most active members of the organization. ${ }^{7}$

The peculiarity of the 'Crimean solidarity' is dominance in its ranks with people with a strong Islamic identity, who until 2014 was on the other side of the Mejlis and SAMC coalition. A significant part of the leadership of

5 The Crimean Tatar National Movement for the return to Crimea has been established in the 1960s in the places of the Crimean Tatars' exile in Central Asia.

6 Dilyaver Memetov is the son of one of the arrested Crimean Tatars, Remzi Memetov, who in December 2018 was sentenced to 17 years.

7 For example, on March 27, 2019, there were arrests of 27 people in the city of Simferopol and Simferopol district, many of whom were active members of the 'Crimean solidarity' (V Krymu...2019). 
The Transformation of the Crimean Tatars' Institutions and Discourses After 2014

the 'Crimean solidarity' is the Crimean Tatars previously associated with the Islamic Party of Liberation (HT), which describes its ideology as Islam and its aim as the re-establishment of the Islamic Caliphate to resume the Islamic way of life in the Muslim world. The party rejects Western political ideas, such as liberalism, nationalism, and democracy, but, in contrast to other Islamic groups, advocates nonviolent methods of struggle (Muratova 2014, 11). In Crimea, HT started to operate openly in the 1990s and held many conferences, rallies, and protests and published the newspaper 'Revival' (Vozrojdenie). Its activity was of great concern to the SAMC and the Mejlis, whose leaders constantly criticized it for being alien to the Crimean Tatar traditions (Bogomolov et al. 2006, 60-62). Unlike the other post-Soviet countries, the party was not (and still not) banned in Ukraine, ${ }^{8}$ and the Crimean office of HT for many years had functioned as a coordinating center of this party in the whole post-Soviet area.

With the arrival of Russia in Crimea, where HT is considered as an extremist organization, party members began to be subjected to pressure. According to the Crimean Human Rights Group, as of April 2019, 55 people were arrested (V ramkakh...2019). Some of them had already received prison sentences, while others were still under investigation. The very detention of these people was accompanied by large-scale special operations of the Russian Center for combating extremism (the so-called 'Center E'), which were carried out early in the morning with cordon off streets and involvement of several dozen armed men. As a rule, detentions were preceded by searches in the houses of these people, during which security forces seized phones, computers, and other equipment. The families of detained and arrested representatives of the HT later formed the core of the 'Crimean solidarity'.

Bringing together different people with different backgrounds within the 'Crimean solidarity' became possible only after the annexation, when former opponents came closer to each other under the pressure of a common threat - the repression of the Russian state. The Mejlis helped 'Crimean solidarity' to gain legitimacy beyond the Crimea, helping its activists to get access to Ukrainian and international human rights institutions. 'Crimean solidarity', in its turn, provides human resources (based on the members of HT) to accomplish certain public initiatives in Crimea that the Mejlis is not able to organize anymore. For example, the activists of the 'Crimean solidarity' ensure the presence of supporting people during searches and arrests, where they video what is happening and make these events public; they also hold

8 Although in 2009, there was an attempt by the head of the Crimean branch of the Ministry of Internal Affairs of Ukraine general Moskal to ban it (Moskal trebuet...2009). 
protest actions all over Crimea, for example, single pickets in October 2017 (Nikiforov 2017).

Finding such different people within the 'Crimean solidarity' inevitably led to the transformation of their discourses. First, activists of the organization do not publicly associate themselves with HT, which is understandable, given its status in the Russian Federation. Besides, they seek to get away from exclusively Islamic rhetoric, which previously dominated among them and was causing acute irritation among the Mejlis and secular-oriented circles of the Crimean Tatar society (see Bogomolov et al. 2006, 62-63). No statements about the perniciousness of Western influence, failure of democracy, or rejection of nationalism are longer heard. These topics disappeared from the rhetoric of HT members also because its representatives began to speak at different Western human rights platforms, where it would be strange to voice such ideas.

Second, it is interesting how 'Crimean solidarity' activists position victims of the Russian regime. Concepts such as 'Muslims of Crimea,' 'Crimean Tatars,' and 'Crimean Tatar people' are used as synonyms.

The offensive on active people is getting stronger every day. It will go as long as we have the spirit of collectivism, general assistance, and the spirit of the fact that we are Crimean Tatars, the Muslims in Crimea want to help each other and do not leave each other in trouble. When we constantly come to searches, we give support to families who are left without breadwinners, sons, and fathers. As long as they do not destroy it, the pressure on our people will continue. ${ }^{10}$

Moreover, activists readily supported the initiative of the Mejlis to name all the detained, kidnapped, or arrested after the annexation of Crimea people as 'political victims' of the regime or 'prisoners of the Kremlin'.

Third, the 'Crimean solidarity' activists began to use the same victimization narratives developed by the Mejlis. In particular, at the monthly held public meetings of the organization, people discuss current Russia's pressure on the Crimean Tatars as another episode in the long history of their suffering at the hands of Russia/USSR. The same events of ethnic history as the first annexation of Crimea and deportation are remembered.

Our people has suffered many trials and difficulties. But the worst was the deportation. The enemies began to take measures to destroy our people more than 200 years ago. During the annexation of $\mathbf{1 7 8 3}$,

9 One of the most famous activists of the 'Crimean solidarity' lawyer Emil Kurtbedinov has even received in 2017 the international human rights award «Front Line Defenders» (Koshelev 2017).

10 The speech of public defender Mustafa Seidaliev at the monthly meeting of the 'Crimean solidarity' on April 28, 2019. 
thousands of people were killed. Hundreds of thousands were forced to leave their homes to save lives. In 1944, having labeled our people the traitors, they loaded it into wagons and deported them. Our grandfathers hoped that this would not happen to our people again. But today, having hung a new label of terrorists, having replaced animal wagons with auto-servants, our people continue to be deported, only now to Russian prisons. ${ }^{11}$

Fourth, the red line in the rhetoric of the activists is the idea that nowadays persecution is not the persecution of supporters of one particular group (namely HT) but the persecution directed against the entire Crimean Tatar people. They try to convince people outside their group that sooner or later representatives of other groups and organizations within the Crimean Tatar society could also find themselves as victims, because the regime is antiCrimean Tatar in its nature. For this reason, 'Crimean solidarity' activists believe that it is shortsighted to amuse themselves with the idea that you can stay away. Instead, everyone, according to them, needs to show active support to those who are being persecuted at the moment.

There is a system, and for this system, raw materials are needed ... Today, some people fall into the millstones of this system. There is no need to harbor illusions - tomorrow others will fall ... We cannot stop this system ... But each of us can provide support. Come and visit the family of the victim, do not say that they deserved it ... When we say that strength is in unity, this is not some kind of philosophical notion or abstract thing. The unity lies in the fact that you, despite some disagreements or different positions on some issues, unite around a common threat and make efforts to counter it. ${ }^{12}$

The activists of 'Crimean solidarity' stress that their organization is not an organization of a particular group but a platform for everyone in Crimea willing to peacefully resist the regime.

Crimean solidarity is not a localized union. This is a people platform.

This is the Crimean Tatar people. These are the Crimean Tatars and all those who joined the peaceful resistance in the Crimea. ${ }^{13}$

Not only the discourse of the 'Crimean solidarity' has mixed, hybrid composition but the activity too. It goes in line with the general course of the Crimean Tatars' struggle developed back to the 1960s based on nonviolent

11 The speech of the public defender Server Cholakchik at the monthly meeting of 'Crimean solidarity' on March 31, 2019.

12 The speech of the lawyer Nazim Sheikhmambetov at the monthly meeting of 'Crimean solidarity' on April 28, 2019.

13 The speech of the coordinator of the project 'Crimean childhood' Mumine Salieva at the monthly meeting of 'Crimean solidarity" on March 31, 2019. 
resistance and also contemporary security considerations (see Žídková and Melichar 2015, 105). Human rights protection is an important part of it. The organization has a quite big group of lawyers, consisting of those who lived in the Crimea before annexation and managed to obtain Russian legal certificates after it and those who came to Crimea from Russia particularly to defend victims of Russian persecution. The last are people with different ethnic and religious backgrounds. All of them handle cases of detained and arrested Crimean Tatars, represent them in courts, file appeals, etc.

Another activity of the organization is civil journalism. Its representatives are constantly present at searches and arrests of the Crimean Tatars. A rapid warning system based on social media involvement has been developed and allows them to quickly arrive at the scene. From there, they conduct online reports and post them on social media. These reports have become the main source of information about the ongoing repressions in Crimea, as the local media either ignore this information totally or present it from security services official stance.

Charity is another important part of the 'Crimean solidarity' activities. It involves the provision of material assistance to detained and arrested people and their family members. For example, the activists initiated several fundraising projects intending to help prisoners to pay their fines. In the framework of the charitable activities, there is a project 'Our children' (Bizim balalar) that aimed to provide financial help to children whose fathers were imprisoned. It was initiated by well-known representatives of the Crimean Tatar media Lilya Budzhurova and Elzara Islyamova. Various educational and recreational activities are also organized for the children within this project. Another children's initiative is 'Crimean childhood' (Krymskoe detstvo), which is primarily directed at the religious education of children. According to its coordinator Mumine Salieva, there were already 180 children whose fathers were imprisoned at the end of April 2019.

Finally, psychological support for families of the victims is another part of the 'Crimean solidarity' work. The monthly meetings of this organization have an important therapeutic function, when mothers, wives, and sisters of detainees have the opportunity to exchange information, to say about the situation of their loved ones, and sometimes to read their letters, appeals, and even poems written in prison.

\section{Concluding Remarks}

The appearance of 'Crimean solidarity' took place in the period of crisis caused by the Russian annexation of Crimea when the Crimean Tatar community 
was trying to get used to new, mainly perceived as hostile, reality. It was a time when traditional institutions (Mejlis, Muftiate, etc.) were not able to provide solutions to broad social problems and address challenges introduced by the new political and institutional environment. In this situation of uncertainty and growing pressure from the new authorities of Crimea, a new organization with hybrid composition and ideology came into play. During several years of its operation in Crimea, the 'Crimean solidarity' showed a better ability to adapt to the turbulent environment than the two original (pure) organizational forms from which it originates - the Islamic Party of Liberation and the Mejlis (genetically grown from the Crimean Tatar National Movement). The essential combination of their organizational principles proved to be advantageous and allowed 'Crimean solidarity' to react more flexible and without being tied to one specific logic of action.

The hybridity of the 'Crimean solidarity' can be found at organizational, ideological, and operational levels. At the level of organization, it follows the logic of action of the HT with its close relationship between the members based on Islamic brotherhood, mutual aid, and reciprocity. This helps the organization's members to continue their activities in the face of ever-increasing pressure. Activities in the name of affected brothers and sisters give them greater dedication and motivation. At the same time, the 'Crimean solidarity' inherited the nonviolent form of resistance developed back to the 1960s by the Crimean Tatar National Movement and later used by the Mejlis. Participation in the organization of people of different age categories - mainly young and middle aged from the HT and older people from the National Movement creates a feeling of unity, erasing age and organizational boundaries, as well as representation of the whole Crimean Tatar people.

At the ideological level of 'Crimean solidarity,' there is also a mixture of various ideas, concepts, and narratives. The presence of Islam in the organization's activities is very noticeable both in the appearance of its activists (beards for men, scarves on women's heads) and the way they perform activities (separation of men and women during monthly meetings, reading Muslim prayers there). Although religious motifs are still very sound in the rhetoric of members of this organization, it also incorporates important topics from the secular discourse of the Mejlis, particularly, deportation and victimization narratives. This is intended to reduce the dividing line between the secular and religious parts of the Crimean Tatar people, to attract as many people as possible to the activities of the organization and to enlist its support. The usage of the secular discourse of the Mejlis is also done to level out the official discourse of the authorities that only members of the HT are persecuted in 
Crimea. The activists of the organization seek to position the affected people as political victims of the regime and the repressions themselves as repressions against the entire Crimean Tatar people.

At the operational level, this hybrid organization with a strong religious background is coping with a set of activities that previously were done mainly by secular institutions. These include human rights, journalism, charity, and other activities. The emphasis on human rights activities suggests that the current generation of the Crimean Tatars has adopted the strategy of resistance of generations of the Soviet period. The 'Crimean solidarity' seeks to build ties with both Russian and international human rights organizations. In a situation of limited political opportunities, many Crimean Tatar activists previously involved in the system of the Mejlis and public organizations saw opportunities for their self-realization in human rights activism. They are also pushed toward this by the general atmosphere of insecurity in Crimea, when the persecution of individual members of the Crimean Tatar community is perceived by many as persecution on ethnic grounds. Thus, human rights activism becomes the predominant model of ethnic consolidation in Crimea. Using existing typologies in the third-sector studies, it is possible to name the 'Crimean solidarity' as the 'shallow hybrid' (Billis 2010, 59), which means that by now it is an organization in which the process of hybridization is low but is constantly moving to the 'entrenched' hybrid with a more profound level of hybridization. This is also consonant with what Skelcher and Smith called 'assimilated hybrid,' an organization in which the core or original logic remains but adopts some of the practices and symbols of a new logic (Skelcher and Smith 2015, 441-442). This means that 'Crimean solidarity' keeps the original logic of HT's institution development but adopts some practices and narratives of the Mejlis and the Crimean Tatar National Movement. The 'Crimean solidarity' can also be regarded as 'organic hybrid' (Billis 2010, 61), an organization that was born as a pure type (in the form of Islamic party) but is moving slowly toward a more hybrid organizational form.

Certainly, the phenomenon of 'Crimean solidarity' shows the blurring of lines between secular and religious, ethnic and Islamic in the Crimean Tatar society. It particularly shows how people with different backgrounds and agendas leave their differences aside to support each other in the face of real and imagined threats to societal security. Of course, this seemingly ideal situation has many nuances that need to be further studied and explained. At this stage, it is difficult to say what lies ahead of this hybrid organization: whether it will become a strong organization, following the example of which other ethnic organizations of the Crimean Tatars will be created, or 


\section{The Transformation of the Crimean Tatars' Institutions and Discourses After 2014}

differences between activists with a different understanding of the future of the Crimean Tatars will prove to be so significant that the hybrid will become ineffective. The literature on hybridity shows that hybridization may lead to the loss of the organization's ideology and general orientation, and hybrids can experience intraorganizational tensions that can be of different nature and bring up various consequences. Much depends on environmental change and on the ability of leaders to have a strategic vision for the future.

\section{References}

Allworth, Edward, ed. 1998. The Tatars of Crimea: Return to the Homeland - Studies and Documents. Durham and London: Duke University Press.

Aydın, Filiz Tutku. 2014. "Crimean Tatars and Russia’s Annexation of Crimea." Turkish Policy Quarterly 13 (3): 81-92.

Bassi, Andrea. 2014. "Book Review. Hybrid Organizations and the Third Sector: Challenges for Practice, Theory and Policy, David Billis." De Gruyter. Nonprofit Policy Forum 5(2): 395-401.

Belitser, Natalya. 2016. Kryms'ki tatary yak korinnyi narod: istoriia pytannia $i$ suchasni realii [The Crimean Tatars as indigenous people: the history of the question and contemporary realities]. Kyiv: Ministry of Information Policy.

Billis, David. 2010. “Towards a theory of hybrid organizations." In Hybrid organizations and the third sector: challenges for practice, theory and policy, edited by David Billis, 46-69. Basingstoke, Hampshire, UK: Palgrave Macmillan.

Bogomolov A.V. et.al. 2006. Islamskaya identichnost'v Ukraine [Islamic identity in Ukraine]. Kiev: Stilos.

Brandsen, Taco, Van de Donk, Wim and Putters, Kim. 2005. "Griffins or Chameleons? Hybridity as a Permanent and Inevitable Characteristic of the Third Sector." International Journal of Public Administration 28: 749-765.

Brandsen, Taco, Karré, Philip Marcel. 2011. "Hybrid Organizations: No Cause for Concern?” International Journal of Public Administration 34: 827-836.

Buhari-Gulmez, Didem. 2018. "'Crisis' and Crimean Tatars: Discourses of Self-determination in Flux." In Crisis and Change in Post-Cold War Global Politics. Ukraine in a Comparative Perspective, edited by Erica Resende, Dovile Budrytė, Didem Buhari-Gulmez, 203224. Palgrave Macmillan.

Dollenberg, Lana. "FSB 'tryaset' krymskikh musulman [FSB "shakes” the Crimean Muslims].” 2014. Krymrealii. August 15. https://ru.krymr.com/a/26532818.html.

Dzhabrail, Abu. "Muftiyat Kryma posetila delegatsiya iz Rossii vo glave s Ravilem Gainutdinovym [The delegation of Crimea led by Ravil Gainutdinov visited the Muftiyat of Crimea].” 2014. Golos Islama. March 28. https://golosislama.com/news.php?id=22805.

"Dzhemilev: Muftii Kryma - truslivaya, deshevaya kukla v rukakh okkupantov [Dzhemilev: Mufti of Crimea is a cowardly, cheap doll in the hands of invaders]." 2016. QHA-Agentstvo krymskie novosti. January 13. http://old.qha.com.ua/ru/politika/djemilev-muftii-krimatruslivaya-deshevaya-kukla-v-rukah-okkupantov/153622/. 
Hoon, Chang Yau. 2006. "Assimilation, Multiculturalism, Hybridity: The Dilemmas of Ethnic Chinese in Post-Suharto Indonesia." Asian Ethnicity 7(2): 149-166.

Ifekwunigwe, Jayne. 1999. "Old whine, new vassals: are diaspora and hybridity postmodern inventions?" In New ethnicities, old racisms? edited by Phil Cohen, 180-204. London, Zed Books.

"Kontaktnaya gruppa po pravam cheloveka v Krymu rasskazala o narusheniyakh silovikov [The contact group on human rights in Crimea told Aksyonov about violations of security forces]." 2014. Krymrealii. October 30. https://ru.krymr.com/a/26666518.html.

Koshelev, Maxim. "Krymskii advokat Kurbedinov - 'zaschitnik na linii ognya' [Crimean lawyer Kurbedinov - 'defender in the line of fire'].” 2017. Gromads'ke. May 26. https:// hromadske.ua/ru/posts/krymskyi-advokat-kurbedynov-zashchytnyk-na-lynyy-ohnia.

Kouts, Natalya and Muratova, Elmira. 2015. "The Past, Present, and Future of the Crimean Tatars in the Discourse of the Muslim Community of Crimea”. Anthropology and Archeology of Eurasia. 53 (3): 25-65.

“Kto 'podstavlyaet' krymskikh musulman? [Who 'substitutes' the Crimean Muslims?]." 2016. Statement of the press-service of the SAM Crimea. October 19. The archive of the author.

"Moskal' trebuet ot SBU zapretit' partiyu 'Hizb ut-Takhrir' [Moskal' demands from the SBU to ban party 'Hizb ut-Tahrir']." 2009. ForPost. September 17. https://sevastopol.su/news/ moskal-trebuet-ot-sbu-zapretit-partiyu-hizb-ut-tahrir.

Muratova, Elmira. 2008. Islam v sovremennom Krymu: indikatory i problemy protsessa vozrojdeniya [Islam in Modern-day Crimea: Indicators and Problems of the Process of Revival]. Simferopol: Elinio.

Muratova, Elmira. 2014. "Islamskie gruppy Kryma: Diskursy i politika [Islamic Groups of Crimea: Discourses and Politics].” Anthropology \& Archeology of Eurasia 53 (3): 9-24.

Muratova, Elmira. 2016. “Krymskie musul'mane v novoi politicheskoi real'nosti [Crimean Muslims in New Political Realities]." Oriens 5 (1): 163-71.

Nikoforov, Vadim. 2017. "Krymskie tatary vyshli na odinochnye pikety v znak protesta protiv deistvii silovikov [Crimean Tatars went to single pickets in protest against the actions of security forces]." Commersant. Accessed May 11.

Nikolko, Milana. 2018. "Collective Trauma, Memories, and Victimization Narratives in Modern Strategies of Ethnic Consolidation: The Crimean Tatar Case." In Crisis and Change in Post-Cold War Global Politics. Ukraine in a Comparative Perspective, edited by Erica Resende, Dovilè Budrytė, Didem Buhari-Gulmez, 69-96. Palgrave Macmillan.

"Novyi Tavricheskii muftiyat - instrument integratsii c RF - ekspert [New Tavrichesky Muftiate - a tool for integration with the Russian Federation - expert]." 2014. Rianovosti. August 22. https://ria.ru/20140822/1021033752.html.

Osipov, Alexander. 2014. "What do the Crimean Tatars face in Crimea?" European Center for Minority Issues - Issue Brief 32.

Ozcelik, Sezai. 2015. Analysis of the Crimean Tatars situation during the occupation of Crimea by Russia in 2014 with the conflict and peace studies approach. E-journaloflaw 1(1): 11-19.

Pelliccia, Andrea. 2017. "Identities in Transition: Hybridism amongst Second Generation Greek Migrants." Athens Journal of Mediterranean Studies. 3(1): 55-74. 
The Transformation of the Crimean Tatars' Institutions and Discourses After 2014

"Postanovlenie Kurultaya krymskotatarskogo naroda 'O zadachakh organov natsional'nogo samoupravleniya po ukrepleniyu dukhovnogo edinstva krymskotatarskogo naroda' [Resolution of the Qurultay of the Crimean Tatar people 'On the tasks of national selfgovernment bodies to strengthen the spiritual unity of the Crimean Tatar people']", Kryms'kotatars'ke pytannya, 1:35 (2010), 65-66.

Shakirov, Ilgiz. "Kto i pochemu pokhischaet krymskikh tatar v Krymu? [Who and why kidnaps Crimean Tatars in Crimea?].” 2014. Krymrealii. October 14. https://ru.krymr. com/a/26636024.html.

Shevel, Oxana. 2000. Crimean Tatars in Ukraine: The Political of Inclusion and Exclusion. Analysis of Current Events 12 (1-2): 9-11.

Skelcher, Chris and Smith, Stevan. 2015. "Theorizing hybridity: institutional logics, complex organizations, and actor identities: the case of nonprofits." Public Administration 93(2): 433-448.

Smith, Stevan. 2010. "Hybridization and nonprofit organizations: The governance challenge." Policy and Society 29(3): 219-229.

"V Kieve sozdano Dukhovnoe upravlenie musul'man Kryma [In Kiev, created the Spiritual Administration of Muslims of Crimea]." 2016. Tsentr zhurnalistskikh rassledovanii. November 20. https://investigator.org.ua/topnews/190850/.

"V Krymu FSB odnovremenno provodit minimum 25 obyskov [In the Crimea, the FSB simultaneously conducts at least 25 searches]." 2019. Ukrainskaya pravda. March 27. https:// www.pravda.com.ua/rus/news/2019/03/27/7210317/.

Vozgrin, Valeriy. 2013. Istoriia krymskikh tatar. Ocherki etnicheskoi istorii korennogo naseleniia Kryma $v$ chetyrekh tomakh [The history of the Crimean Tatars. Essays on the ethnic history of indigenous population of Crimea in four volumes]. St. Petersburg: Nestor-Istoriia.

"V ramkakh politicheskikh i religioznykh presledovanii v Krymu lisheny svobody 86 chelovek [Within the framework of political and religious persecution in Crimea 86 people are imprisoned]." 2019. Crimean human rights group. May 3. https://crimeahrg.org/v-ramkahpoliticheskih-i-religioznyh-presledovanij-v-krymu-lisheny-svobody-86-chelovek/.

"Vse mecheti Kryma doljny byt' peredany v Muftiyat, - Balbek [All the mosques of the Crimea must be transferred to the Muftiate, - Balbek]." 2018. Krymskoe informatsionnoe agentstvo. November 20. https://kianews24.ru/news/vse-mecheti-krima-dolzhni-bit-peredani/.

“Vystuplenie M. Dzhemileva. Dokumenty pervoi sessii V Kurultaya (dekabr' 2007 g.) [Speech by M. Dzhemilev. The documents of the first session of the V Qurultay].” 2008. Kryms'kotatars'ke pytannya 1(30): 86-95.

Waever, Ole. 1993. "Societal Security: The Concept." In Identity, Migration and the New Security Agenda in Europe, edited by Ole Wrever, Barry Buzan, Morten Kelstrup and Pierre Lemaitre, 17-40. New York: St. Martin's Press.

Williams, Brian. 2015. The Crimean Tatars: from Soviet Genocide to Putin's Conquest. New York: Oxford University Press.

Wilson, Andrew. 2017. "The Crimean Tatar Question: A Prism for Changing Nationalisms and Rival Versions of Eurasianism." Journal of Soviet and Post-Soviet Politics and Society 3 (2): $1-45$. 
Journal of Nationalism, Memory \& Language Politics 13(1)

Yapici, Utku. 2018. Change in the Status of the Crimean Tatars: from National Minority to Indigenous People? Bilig. Türk Dünyası Sosyal Bilimler Dergisi Sayı 85: 299-332.

Žídková, Marketa and Melichar, Hynek. 2015. "Crimean Tatars Before and After the Annexation of Crimea: Identity, Societal Security, and the Prospects of Violence". ALPPI Annual of Language \& Politics and Politics of Identity 9: 87-112. 